\title{
Isolation and Identification of Native Bacteria from Total Petroleum Hydrocarbon Polluted Soil in Wonocolo Public Oilfields, Indonesia
}

\author{
Gina Lova Sari ${ }^{1 *}$, Yulinah Trihadiningrum², Ni'matuzahroh ${ }^{3}$ \\ 1 Faculty of Engineering, Universitas Singaperbangsa Karawang, Teluk Jambe Timur, Karawang 41361, \\ Indonesia \\ 2 Department of Environmental Engineering, Faculty of Civil Engineering, Environment, and Geoscience, \\ Institut Teknologi Sepuluh Nopember, Surabaya 60111, Indonesia \\ 3 Department of Biology, Faculty of Science and Technology, Airlangga University, Surabaya 60115, Indonesia \\ * Corresponding author's e-mail: ginalovasari@gmail.com
}

\begin{abstract}
The presented study concerns on isolation and identification of indigenous bacteria in total petroleum hydrocarbon (TPH) polluted soil.. The composite TPH polluted soil was collected from Wonocolo public oilfields, Indonesia.. Pour plate and plate count techniques were used to bacterial population analysis and enumeration, respectively. Two dominant bacterial colonies were isolated from $4.06 \times 10^{7} \mathrm{CFU} / \mathrm{g}$ population in polluted soil, then morphologically and biochemically were characterized using Microbact Identification Kits (Microbact ${ }^{\mathrm{TM}}$ GNB12A and 12B). The identification of isolated bacteria was performed using Bergey's Manual of Determinative Bacteriology. The results showed that the strains of bacteria are Bacillus $s p$. and B. cereus with probability of 72.00 and $77.00 \%$, respectively. These strains potentially acted as biosurfactant producers and hydrocarbon degraders. Thus, biostimulation could be implemented to reduce the TPH levels in polluted soil at Wonocolo public oilfields.
\end{abstract}

Keywords: Bacillus sp., B. cereus, TPH polluted soil, Wonocolo public oilfields.

\section{INTRODUCTION}

The crude oil exploration activities in Wonocolo public oilfields caused soil and surface water contamination of total petroleum hydrocarbons, TPH (Handrianto et al., 2012; Sari et al., 2018). Our previous study reported that topsoil in Wonocolo public oilfields was highly polluted by TPH in a range of 52,328.14-107,189.63 $\mu \mathrm{g} / \mathrm{g}$ (Sari et al., 2018). TPH constitute hydrophobic compound that are toxic, mutagenic, and carcinogenic. The accumulation of TPH in soil may cause plant, animal, and human tissues to be damaged as they transport in biomagnification chain (Xu and Liu, 2010; Kumari et al., 2013). Therefore, the topsoil at Wonocolo public oilfields need bioremediation to avoid the impact on the people and environment in the local area (Sari et al., 2018). Bioremediation is an effective method to reduce the TPH level in polluted soil with feasibility cost. Several studies reported that the bioremediation effectiveness for TPH degradation reaches up to $80 \%$ (Handrianto et al., 2012; $\mathrm{Xu}$ and Liu, 2010; Asquith et al., 2012; Darmayanti et al., 2017).

Bioremediation, biostimulation and/or bioaugmentation, is defined as the process that utilizes the metabolic capabilities of microorganisms for TPH uptake and degradation into less toxic substance, or their removal from polluted soil. Biostimulation and bioaugmentation aim at increasing the level of TPH biodegradation by microorganisms. The difference of both techniques is bacteria used, where biostimulation and bioaugmentation use indigenous and specific competent exogenous bacteria introduced to the process, respectively (Xu and Liu, 2010; Asquith et al., 2012). Both bacteria were stimulated through environmental factors (nutrient, oxygen, moisture, $\mathrm{pH}$, and temperature) monitoring 
to enhance the effectivity of TPH degradation (Xu and Liu, 2010; Das and Chandran, 2011).

The viability of bacteria has been found to be useful in both bioremediation process. This study aimed at isolating and identifying the bacteria in polluted soil from Wonocolo public oilfields. It was necessary to determine the required technique for better TPH biodegradation performance. In addition, the potential role of bacteria in bioremediation process was reviewed.

\section{MATERIALS AND METHODS}

\section{TPH polluted soil collection}

The TPH polluted soil was taken in April 2017 from 0 to $30 \mathrm{~cm}$ below the surface of three contaminated sites at Wonocolo public crude oilfields. The description of the sites, soil sampling procedures, and the preparation were reported in our previous study (Sari et al., 2018).

\section{MICROBIAL ANALYSES}

\section{Determination of bacterial population}

Pour plate and plate count methods were used for bacteria population analysis and enumeration. One gram of soil was mixed with $50 \mathrm{~mL}$ of $\mathrm{NaCl}$ $(0.8 \%) .1 \mathrm{~mL}$ of the mixture was diluted from $10^{-1}$ to $10^{-10}$ or more. $1 \mathrm{~mL}$ of dilution liquid was subculture into nutrient agar (NA) and incubated for 24 hours at a room temperature. After 24 hours of incubation, bacteria colonies forms were counted (Cappucino and Sherman, 1983).

\section{Isolation, characterization, and identification of bacterial strain}

The dominant bacteria colonies were subcultured on the NA using a streak method following Olukunle (2013). Morphological of selected colony such as color, shape, edge, and size were observed using microscope. The selected colony was picked for cellular morphological characterization through Gram staining analysis (Balows, 1992). Meanwhile, the biochemical characteristics of selected colony were performed using Microbact Identification Kits (Microbact ${ }^{\mathrm{TM}}$ GNB12A and 12B). Furthermore, individual bacterial strain was identified according to Bergey's Manual of Determinative Bacteriology (Holt et al., 1994).

\section{RESULTS AND DISCUSSION}

\section{Total population and characterization of bacteria isolated from TPH polluted soil}

The population of bacteria in TPH polluted soil amounted to $4.06 \times 10^{7} \mathrm{CFU} / \mathrm{g}$ with two dominant colonies. This indicates that bacteria are able to adapt with the presence of TPH in the polluted soil (Sari et al., 2016). The morphological characteristics of the colonies are presented in Table 1, and classified as gram-positive bacteria with basic forms of bacilli (Fig. 1).

The biochemical characteristics of bacteria (Table 2) show that colony 1 exhibited motility (using flagella to move). Furthermore, it also produces many enzymes such as oxydase, catalase, nitrate reductase, gelatinase, and voges proskauer. Barely same characteristics showed by Colony 2 are motility and enzyme producers (oxydase, amylase, catalase, nitrate reductase, and voges proskauer). The capabilities show that colony 1 and 2 may play a role in organic matter decomposition. However, both colonies are unable to ferment lactose and sucrose into glucose.

\section{Identification of bacterial strain}

On the basis of morphological and biochemical characteristics, two isolate colonies may belong to Bacillus genera. Furthermore, the prediction was confirmed that Bergey's Manual of Determinative Bacteriology which identified colony 1 and 2 belong to Bacillus sp. (72.00\%), and B. cereus $(77.00 \%)$ strains, respectively. Prakash et al. (2014) confirmed that Bacillus sp.

Table 1. Morphological characteristics of bacteria isolated

\begin{tabular}{|c|c|c|c|c|c|}
\hline \multirow{2}{*}{ Bacteria } & \multicolumn{5}{|c|}{ Morphological characteristics } \\
\cline { 2 - 6 } & Color & Shape & Edge & Size $(\mathrm{cm})$ & Gram Strain \\
\hline Colony 1 & White & Irregular & Undulate & 0.30 & + \\
\hline Colony 2 & White & Circular & Filiform & 0.20 \\
\hline
\end{tabular}



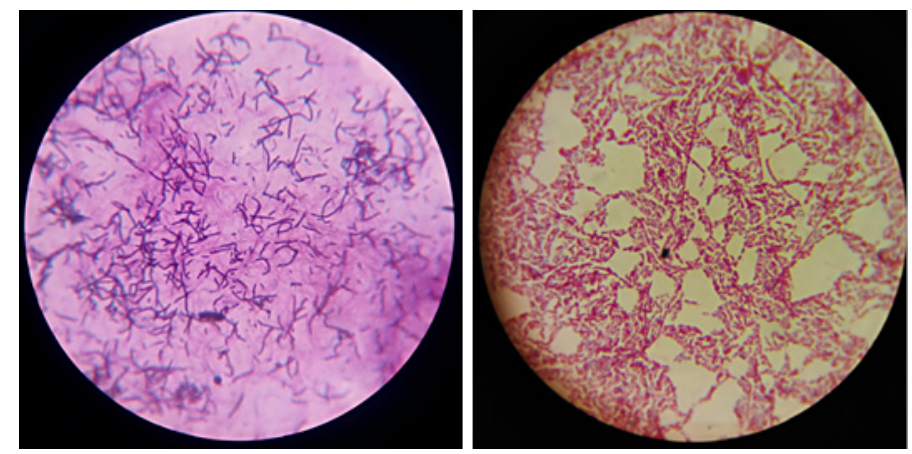

Figure 1. Gram strain colony 1 (left); colony 2 (right)

is one of indigenous bacteria in crude oil contaminated soil. Meanwhile, B. cereus is indigenous bacteria in diesel contaminated soil (Bento et al., 2005). Both conditions are in accordance to Wonocolo public oilfields that exploit crude oil and produce heavy diesel.

The presence of both indigenous strains in TPH polluted soil indicates that the bacteria might utilize the hydrocarbon as carbon and energy source to grow (Das and Chandran, 2011). Therefore, the indigenous bacteria in polluted soil could be responsible for TPH removal in bioremediation process (Kumari et al., 2013; Darmayanti et al., 2017; Balows, 1992). Olukunle (2013) stated that the capability of indigenous bacteria showed a possibility of in situ bioremediation which is an economical technique.

Role of Bacillus sp. and B. cereus in Bioremediation of TPH-Polluted Soil

Several researchers reported that Bacillus sp. and $B$. cereus are capable of acting as hydrocarbon degraders (Das and Chandran, 2011; Prakash et al., 2014; Cerqueira et al., 2011). Bacillus sp. and $B$. cereus can reduce the concentration of benzene up to $54.80 \%$ (Prakash et al., 2014) and 92.59-95.37\% (Ole, 2017), respectively. It is due to Bacillus strain being able to produce surface active compounds, also known as biosurfactants, which could reduce surface tension and emulsify hydrocarbon (Cerqueira et al., 2011; Yangejeh et al., 2017).

Several studies reported that the surface tension of Bacillus sp. and B. cereus are lower than distilled water $(73.05 \mathrm{mN} / \mathrm{m}$ ) of 24.60 (Zhou et al., 2015) and $25.00 \mathrm{mN} / \mathrm{m}$ (Tuleva et al., 2005), respectively. Simultaneously, it facilitates hydrocarbon attack and diffusion into bacterial cells (Yangejeh et al., 2017) through affinity improvement in the change of the cell surface hydrophobicity (Kumar et al., 2007). The ability review of Bacillus sp. and B. cereus is presented in Table 3.

\section{CONCLUSIONS}

The current study confirms that Bacillus sp. and $B$. cereus are dominant indigenous bacteria at Wonocolo public oilfields polluted soil. These bacteria are hydrocarbon degraders and are able to produce biosurfactants. We recommend biostimulation such as composting and landfarming to be used as bioremediation techniques for TPH polluted soil at the site.

\section{Acknowledgements}

The authors gratefully acknowledge the Indonesian Ministry of Research, Technology,

Table 2. Biochemical characteristics of bacteria isolated

\begin{tabular}{|c|c|c|c|c|c|c|c|c|c|c|c|c|c|c|c|}
\hline \multirow[b]{2}{*}{ Bacteria } & \multicolumn{15}{|c|}{ Biochemical characteristics } \\
\hline & 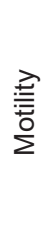 & $\begin{array}{l}0 \\
0 \\
\text { D } \\
\frac{0}{0} \\
\text { Oे }\end{array}$ & 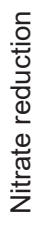 & 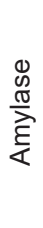 & $\begin{array}{l}0 \\
0 \\
\frac{\pi}{\pi} \\
\frac{\pi}{\pi} \\
0 \\
0\end{array}$ & 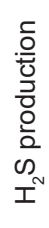 & $\begin{array}{l}\text { 음 } \\
\frac{0}{0} \\
\frac{0}{0} \\
\frac{0}{0} \\
\text { 을 }\end{array}$ & 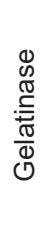 & 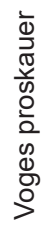 & 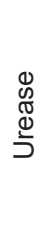 & 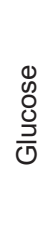 & 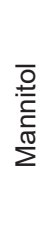 & 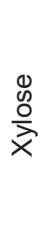 & 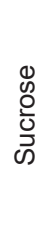 & 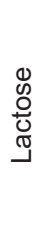 \\
\hline Colony 1 & + & + & + & - & + & - & - & + & + & - & - & - & - & - & - \\
\hline Colony 2 & + & + & + & + & + & - & - & - & + & - & - & - & - & - & - \\
\hline
\end{tabular}


Table 3. The ability of Bacillus sp., and B. cereus

\begin{tabular}{|c|c|c|c|c|}
\hline Bacteria & $\begin{array}{c}\text { Source of Oil- } \\
\text { Contaminated Soil }\end{array}$ & Degradation of Hydrocarbon & Biosurfactant & Reference \\
\hline \multirow{5}{*}{ Bacillus sp. } & Meerut Region & $54.80 \%$ of benzene & - & $\begin{array}{l}\text { Prakash et al., } \\
2014\end{array}$ \\
\hline & $\begin{array}{l}\text { Guanoco Lake, Sucre } \\
\text { State }\end{array}$ & $\begin{array}{l}67.00 \pm 3.00 \text { up } \\
\text { to } 69.00 \pm 4.00 \text { of } \\
\text { Phenantherene }\end{array}$ & Surface tension up to $40 \mathrm{mN} / \mathrm{m}$ & Kumar et al., 2007 \\
\hline & $\begin{array}{l}\text { Oilfield in northwest } \\
\text { China }\end{array}$ & 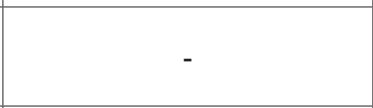 & $\begin{array}{l}\text { Lipopeptide, surface tension of } \\
24.60 \mathrm{mN} / \mathrm{m}\end{array}$ & Zhou et al., 2015 \\
\hline & $\begin{array}{l}\text { Automobile workshop } \\
\text { in Manipal, India }\end{array}$ & - & $\begin{array}{l}\text { Lipopeptide, surface tension } \\
\text { reduction up to } 36.10 \mathrm{mN} / \mathrm{m}\end{array}$ & $\begin{array}{l}\text { Varadavenkatesan } \\
\text { and Murty, } 2012\end{array}$ \\
\hline & Not explained & - & $\begin{array}{l}\text { Lipopeptide, surface tension up } \\
\text { to } 27.80 \mathrm{mN} / \mathrm{m}\end{array}$ & $\begin{array}{l}\text { Hesty and Putra, } \\
2017\end{array}$ \\
\hline \multirow{5}{*}{ B. cereus } & Hongkong, China & - & Surface tension of $50.00 \mathrm{mN} / \mathrm{m}$ & Bento et al., 2005 \\
\hline & $\begin{array}{l}\text { Petrochemical } \\
\text { industry in the city of } \\
\text { Triunfo, Rio Grande do } \\
\text { Sul State, Brazil }\end{array}$ & $\begin{array}{l}\text { - } 88.40 \pm 0.60 \% \text { of aliphatic } \\
\text { hydrocarbon } \\
\text { - } 40.30 \pm 6.70 \% \text { of aromatic } \\
\text { hydrocarbon } \\
\end{array}$ & $\begin{array}{l}\text { - Surface tension of } 41.40 \pm 0.30 \\
\mathrm{mN} / \mathrm{m} \\
\text { - Emulsifying activity of } \\
33.30 \pm 0.10 \%\end{array}$ & $\begin{array}{l}\text { Cerqueira et al., } \\
2011\end{array}$ \\
\hline & Artificial & $92.59-95.37 \%$ of BTX & - & Ole, 2017 \\
\hline & Not explained & $\begin{array}{l}72.00 \pm 4.00 \% \text { of } \\
\text { Naphthalene }\end{array}$ & $\begin{array}{l}\text { Rhamnolipid, surface tension of } \\
25.00 \mathrm{mN} / \mathrm{m}\end{array}$ & Tuleva et al., 2005 \\
\hline & $\begin{array}{l}\text { Cepu, East Java, } \\
\text { Indonesia }\end{array}$ & $54.00 \%$ of $\mathrm{TPH}$ & 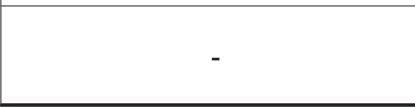 & $\begin{array}{l}\text { Darmayanti et al., } \\
2017\end{array}$ \\
\hline
\end{tabular}

and Higher Education for the Doctoral Dissertation Research Grant, which made this study to work out. The authors gratefully thank to thank Mrs. Mery M. Soesilo, Mrs. Hurun In, Ms. Kartika Primasari from Soild Waste Laboratory of Institut Teknologi Sepuluh Nopember and Biology Laboratory of Airlangga University for their scientific contribution and assistance in sample analysis.

\section{REFERENCES}

1. Asquith, E.A., Geary, P.M., Nolan, A.L., Evans, C.A. 2012. Comparative Bioremediation of Petroleum Hydrocarbon-Contaminated Soil by Biostimulation, Bioaugmentation and Surfactant Addition. J. Env. Sci. Eng., A1, 637-650.

2. Balows, A. 1992. The Prokaryotes: A Handbook on the Biology of Bacteria: Ecophysiology, Isolation, Identification, Applications. Springer-Verlag: Heidelberg, Germany.

3. Bento, F.M., Camargo, F.O.A., Okeke, B.C., Frankenberger, W.T. 2005. Diversity of Biosurfactant Producing Microorganisms Isolated from Soil Contaminated with Diesel Oil. Microbiological Research, 160(3), 249-255.
4. Cappucino, J.G.N., and Sherman, N. 1983. Microbiology: A Laboratory Manual, 8th Edition. Addison-Wesley Publishing Company, California.

5. Cerqueira, V.S., Hollenbach, E.B., Maboni, F., Vainstein, M.H., Camargo F.A.O., Peralba M.C., Bento F.M. 2011. Biodegradation Potential of Oily Sludge by Pure and Mixed Bacterial Cultures. Bioresource Technology, 102, 11003-11010.

6. Darmayanti, Y., Sanusi, HS., Prartono, T., Santosa, D.A., Nuchsin, R. 2017. Optimal Bacterial Density and Fertilizer Dosage for Bioremediation of Oil Contaminated Sandy Beach: A Case of Cilacap, Indonesia. BIOTROPIA, 24(3), 182-191.

7. Das, N., and Chandran, P. 2011. Microbial Degradation of Petroleum Hydrocarbon Contaminants: An Overview. Biotech. Res. Inter.: 1-13.

8. Handrianto, P., Rahayu, Y.S., Yuliani, Y. 2012. The Bioremediation as Solution of Hydrocarbon Contaminated Soil (In Indonesian). Proc. Chemical National Conference, Surabaya: 22-30.

9. Hesty, H., and Putra, M.D. 2017. Kinetic Study and Modeling of Biosurfactant Production using Bacillus sp. Electronic J. Biotech., 27, 49-54.

10. Holt, J.G., Kriey, N.R., Sneath, P.H.A., Staley, J.T. 1994. Bergey's Manual of: Determinative Bacteriology. 9th edition. Lippincott Williams and Wilkins: Baltimore, USA. 
11. Kumar, M., Leon, V., Materano, A.D.S., Ilzins, O.A. 2007. A Halotolerant and Thermotolerant Bacillus sp. Degrades. World J Microbiol Biotechnol., 23, 211-220.

12. Kumari, N., Vashistha, A., Saini, P., Meghani, E. 2013. Isolation, Identification and Characterization of Oil Degrading Bacteria Isolated from the Contaminated Sites of Barmer, Rajasthan. Int. J. Biotech. Bioeng., Res., 4(5), 429-436.

13. Ole, M.A.N. 2017. Bioremediation of Benzene, Toluene and Xylene (BTX) from Petroleum Contaminated Soil by Aerobic Bacteria at Slurry Phase in Bioreactor [In Indonesian]. Thesis: Institut Teknologi Sepuluh Nopember, Surabaya.

14. Olukunle, O.F. 2013. Characterization of Indigenous Microorganisms Associated with Crude OilPolluted Soils and Water Using Traditional Techniques. Microbiology Journal, 3(1), 1-11.

15. Prakash, A., Bisht, S., Singh, J., Teotia, P., Kela, R., Kumar, V. 2014. Biodegradation Potential of Petroleum Hydrocarbons by Bacteria and Mixed Bacterial Consortium Isolated from Contaminated Sites. Turkish J. Eng. Env. Sci., 38, 41-50.

16. Sari, G.L., Mizwar, A., Trihadiningrum, Y. 2016. Soil pH Effect for Polycyclic Aromatic Hydrocarbon (PAH) Biodegradation Process from Coal Contaminated Soil [In Indonesian]. Jurnal Teknologi,
8(1), 31-38.

17. Sari, G.L., Trihadiningrum, Y., Ni'matuzahroh. 2018. Petroleum Hydrocarbon Pollution in Soil and Surface Water by Public Oil Fields in Wonocolo Sub-district, Indonesia [in press]. J. Ecol. Eng.

18. Tuleva, B., Christova, N., Jordanov, B., Nikolova-Damyanova, B., Petrov, P. 2005. Naphthalene Degradation and Biosurfactant Activity by Bacillus Cereus 28BN. J. Bioscie., 60(7-8), 577-582.

19. Varadavenkatesan, T., and Murty, V.R. 2013. Production of a Lipopeptide Biosurfactant by a Novel Bacillus sp. and Its Applicability to Enhanced Oil Recovery. ISRN Microbiology: 1-8.

20. Xu, Y., and Liu, M. 2010. Bioremediation of Crude Oil-Contaminated Soil: Comparison of Different Biostimulation and Bioaugmentation Treatments. J. Hazard. Mater., 183, 395-401.

21. Yangejeh, R.J., Pourjafarian, V., Afrous, A., Gholami, A., Maktabi, P., Sharifi, R. 2017. Studying Bacillus Cereus's Ability to Biodegrade Crude Oil in Hot Areas. Petroleum Sci. Tech., 35(3), 287-291.

22. Zhou, H., Chen, J., Yang, Z., Qin, B., Li, Y., Kong, X. 2015. Biosurfactant Production and Characterization of Bacillus sp. Zg0427 Isolated from Oil-Contaminated Soil. Annals of Microbiology, 65(4), 2255-2264. 